\title{
Combinatory Christology
}

\begin{abstract}
Author:
Dirk Evers ${ }^{1,2}$ (]

Affiliations:

${ }^{1}$ Institute for Systematic

Theology, Practical Theology and Philosophy of Religion, Martin-Luther-University Halle-Wittenberg, Germany

${ }^{2}$ Department of Dogmatics and Christian Ethics, Faculty of Theology, University of Pretoria, South Africa

Project leader: D.P. Veldsman Project number: 01224719

\section{Description:}

Prof. Dr Dirk Evers is professor of Systematic Theology and Philosophy of Religion at the Martin-LutherUniversity Halle Wittenberg, Germany, and part of the research project, 'Religious Experience from an evolutionary perspective', directed by Prof. Dr Danie Veldsman, Department Dogmatics and Christian Ethics, Faculty of Theology, University of Pretoria.
\end{abstract}

Corresponding author: Dirk Evers,

dirk.evers@theologie. uni-halle.de

Dates:

Received: 12 May 2016 Accepted: 19 July 2016 Published: 11 Nov. 2016

How to cite this article: Evers, D., 2016, 'Combinatory Christology', HTS Teologiese Studies/Theological Studies 72(4), a3482. http://dx.doi. org/10.4102/hts.v72i4.3482

\section{Copyright:}

(c) 2016. The Authors. Licensee: AOSIS. This work is licensed under the Creative Commons Attribution License.

\section{Read online:}

\section{Scan this $Q R$} code with your smart phone or mobile device to read online.
This article aims to present Christology not as an add-on to monotheism, but as its specific Christian form. What Christ means can only be explained with reference to God and vice versa; what God stands for in a Christian sense has to be explained with reference to Jesus Christ and not with reference to generic religious terms. Christology thus informs and forms the Christian understanding of how to relate God and reality. Therefore, Christology has to be developed as combinatory Christology bringing different dimensions of reality including scientific and evolutionary perspectives into creative interplay. Theology is an 'art of combination' (Dalferth 1991:18), which in ever new ways relates traditions of faith with theoretical and historical knowledge in order to find relevant ways of understanding God's presence in the world, to articulate the Christian faith in a meaningful way and to form our ways of living in such a way as to conform to God's passion for the life of God's creatures. This article wants to lay grounds for such an endeavour by re-evaluating the history of Christology and combining this analysis with present day challenges.

\section{Preliminary remarks on Christian monotheism}

Christian monotheistic thought ${ }^{1}$ has its centre in the categorical distinction between God and creation. When biblical literature refers to God as the one and only God, it not simply argues for a numerical reduction of many possible Gods to a single individual, but rather is interested in sustaining the fundamental distinction between God as creator and the world of creatures - a distinction not necessarily implied in formal monotheistic thought (Ebeling 1989:397). This strict distinction, however, is intended not to distance God and creation, but to point to the fact that God, who alone is God, is the one who is present within creation and that through this divine presence all creatures 'live and move and have their being' (cf. Ac. 17:28). In a Christian perspective God must not be identified with any contingent, finite and relative entity, but must be understood, not only as the ground and destination of creation, but also as beneficial presence to it. It is the pivotal point of Christian monotheism that it is exactly that one God, who is fundamentally transcendent, who at the same time is present, near and active in creation thus communicating God's divine self to God's creatures. God's presence is a beneficial presence and in the case of human beings this encompasses reconciling human beings among themselves and with God. The emphasis of the distinction between God and creation does not aim at separating but at expressing the relationality between God and creation through God's communicative presence, while at the same time holding on to the fact that presence is not identity.

The central Christian claim that God is near, present and active within creation and that only God as God-self can unite creation with God's divine being, is not an abstract theological insight, but derived from the story and fate of Jesus, in whom Christianity identifies God's pervading, intimate and communicative presence within the life of an individual human being. Here the presence of God within creation becomes visible and effective in such a way that Christianity, right from its beginnings as documented in the New Testament texts tried to identify God and Jesus without dissolving God into creation and without deifying Jesus and turning him into a heavenly being walking on earth in human disguise. In this sense, Christology is the hermeneutical

1.The concept of 'monotheism' suggests a uniformity and clarity of that notion which is neither covered by the history or philosophy of religions nor by theological consensus. The term 'monotheism' first appeared in the 2 nd half of the 17th century. Apparently, it was the Cambridge Platonist Henry More with his fondness for neologism who first used the term 'monotheism' in 1660 and who right from the start differentiated between different versions and filed 'pagan' monotheism together with polytheism under atheism cf. Hülsewiesche (1984:142-146). One only has to compare the three so-called monotheistic world religions and one will realise that different versions of monotheism obtain. Erik Peterson (1994:47), for example, in his tractate on 'Monotheism as political problem' refers to the inner totalitarian tendency of a political theology in line with monotheistic thought and explicitly positions Christian Trinitarian thought beyond the alternative of monotheism and polytheism; cf. Jürgen Moltmann (1993a:131) who states that 'the strict notion of the One God really makes theological christology impossible'.

Note: Original Research: Volume 17 in the South African Science and Religion Forum Series, edited by Prof. Dr Cornel du Toit (UNISA) and Prof. Dr Danie Veldsman, entitled 'Creation, Consciousness and Christology: Evolutionary Perspectives', Proceedings of the 20th conference of the South African Science and Religion Forum (SASRF) of the Research Institute for Theology and Religion held at the University of South Africa, Pretoria 16-18 September 2015.

Additional note: The author's participation in the conference of the South African Science and Religion Forum (SASRF) of the Research Institute for Theology and Religion held at the University of South Africa, Pretoria 16-18 September 2015, was sponsored by the National Research Foundation of South Africa, facilitated by Prof. Dr Danie Veldsman. 
key to Christian monotheism. Consequently, the Council of Chalcedon (451) attempted to assert those fundamental Christological perspectives by stating that in Jesus Christ humanity and the divine come together 'indivisibly and

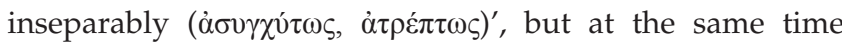

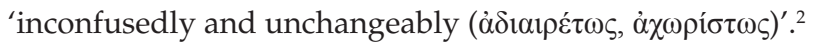

However, the view that the identification of God with a single human individual is not only the hermeneutical key to understanding God's redeeming and reconciling presence in creation, but is also God's decisive and effective communicative act for drawing creation into God's own life, raises the fundamental issue how God's presence in Jesus Christ is mediated to all of creation. If Christ in his teaching and in his life is representing an eternal divine principle, the question is easy to answer: Christ simply reveals what is - in hidden ways - the case everywhere and at all times. If Christ is something like a divine messenger entering our reality from beyond and then again leaving it, the question is more difficult to answer. In this case the life-time of Jesus is the decisive event of the presence of God incarnate, and the question occurs how Christ relates to the human beings and their history before his coming and how he can be thought of as being present after his death and resurrection.

It is my conviction that a renewal of Christology can only be achieved if we find ways to understand God's communicative presence with regard to creation in such a way that God is neither comprehended as an additional principle of reality nor as a supernatural being 'outside' of reality interfering with it from time to time. Part of this renewal must be to re-evaluate the history of Christology. Traditionally, there has been a fundamental divide between liberal or expressivist, and conservative or doctrinal Christologies. This debate has reached a kind of stalemate situation: either Jesus is nothing but a human being, a prophet, a teacher, a role model as believer or religious individual, or Jesus Christ is understood as a supernatural divine-human being, the son of God walking on earth. I still think that this difference between liberal and doctrinal Christology is valid, but I am even more convinced that we have to transform this disjunction into a distinction between different aspects of Christology that have to be held together. If we are able to see Christology as an interrelation of different perspectives on Jesus Christ which are not mutually exclusive, this might allow for the diversification into Christologies that differ in foci but can become positively related.

\section{Christology within an ontological framework}

I start with elaborating on what I call classical Christology in an ontological third-person perspective. It is deeply influenced by classical Western ontology, according to which reality consists of objects that exist relatively independent of human understanding. Every contingent being is a composite system consisting of functional parts and individuated by matter in space and time. However, no being is simply identical with its corporeal appearance. What constitutes a certain being as an individual with an identity in space and over time is that it is an exemplification of a nature. Especially in Aristotelian thinking, it is this nature or essence which is responsible for the identity of a living being throughout its life, although its outer form may change and, indeed, must change, for example after birth, so that a being can become what, according to it's nature, it is meant to be and in a sense already is. And it is due to these natures and essences that objects show certain essential properties. However, it is worth noting that in this concept the living being, the organism, is the paradigm for what is called an individual.

The Latin word natura originally referred to those properties and predispositions which beings have not acquired but which they possess by birth (natus = born). ${ }^{3}$ Soon the Latin term natura adopted the meaning of essence or substance, so that natura came to mean that set of indispensable properties that qualify an entity as an exemplar of a natural kind. ${ }^{4}$ A natural being is something that has a nature ${ }^{5}$ and therefore actually exists as one of a kind. In such a classical ontological view of reality as exemplifying natures in the form of individuals, true knowledge of reality is understood as the mind adequately representing the objective structure of reality. The classical formula for this is Thomas Aquinas' definition that truth is the adequacy of the intellect with what actually is the case. ${ }^{6}$ The human mind is able to represent the objective structure of reality.

Traditional Christology as developed in the early church and defined in the ecumenical Councils of Nicaea and Chalcedon $(325 / 381 / 451)$ tried to spell out Christology in those ontological notions, but was confronted with the problem that in order to understand Christ as the Son of God the

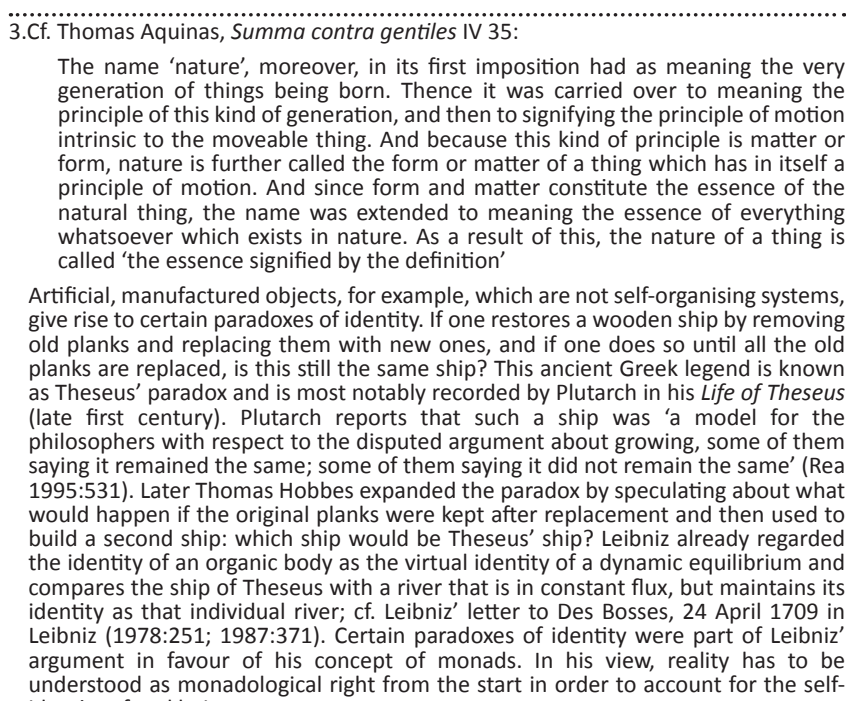

The name 'nature', moreover, in its first imposition had as meaning the very generation of things being born. Thence it was carried over to meaning the principle of this kind of generation, and then to signifying the principle of motion intrinsic to the moveable thing. And because this kind of principle is matter or form, nature is further called the form or matter of a thing which has in itself principle of motion. And since form and matter constitute the essence of the principle of motion. And since form and matter constitute the essence of the natural thing, the name was extended to meaning the essence of everything whatsoever which exists in nature. As a result of this, the nature of a thing is (

Artificial, manufactured objects, for example, which are not self-organising systems, give rise to certain paradoxes of identity. If one restores a wooden ship by removing old planks and replacing them with new ones, and if one does so until all the old planks are replaced, is this still the same ship? This ancient Greek legend is known as Theseus' paradox and is most notably recorded by Plutarch in his Life of Theseus as Theseus paradox and is most notably recorded by Plutarch in his Life of Theseus (late first century). Plutarch reports that such a ship was a model for the philosophers with respect to the disputed argument about growing, some of them saying it remained the same; some of them saying it did not remain the same' (Rea 1995:531). Later Thomas Hobbes expanded the paradox by speculating about what would happen if the original planks were kept after replacement and then used to build a second ship: which ship would be Theseus' ship? Leibniz already regarded the identity of an organic body as the virtual identity of a dynamic equilibrium and compares the ship of Theseus with a river that is in constant flux, but maintains its identity as that individual river; cf. Leibniz' letter to Des Bosses, 24 April 1709 in Leibniz $(1978: 251 ; 1987: 371)$. Certain paradoxes of identity were part of Leibniz argument in favour of his concept of monads. In his view, reality has to be understood as monadological right from the start in order to account for the selfidentity of real beings.

4.Cf. Augustine, De moribus ecclesiae catholicae II 2.2 (CSEL XC, 89.19-20): 'Nature is nothing other than that thing which is understood to be something: ipsa natura nihil est aliud, quam id quod intelligitur in suo genere aliquid esse.'

5.Cf. Thomas Aquinas, Summa contra gentiles IV 35: "Natura" est secundum quam res aliqua dicitur res naturalis: It is [its] "nature" by which something is called a natural thing.'

6.Thomas Aquinas, Summa theologiae I q.16, a.1 corp. 
otherwise impossible combination of two natures in one individual has to be presupposed. The Council of Chalcedon repudiated the notion of a single nature in Christ and famously declared that Jesus Christ has two natures coming together in one person or hypostasis, that is, a self-identical individual. Both natures, human and divine, were proclaimed to be united with neither confusion nor division: human nature was not absorbed by divine nature, neither vice versa. But on the other hand, the one person of Christ cannot be divided in divine and human fractions. This resulted in the traditional doctrine of an intimate communication and exchange of properties between both natures (communicatio idiomatum) within the one, self-identical person. In later dogmatic terms, Christ was understood as persona composta

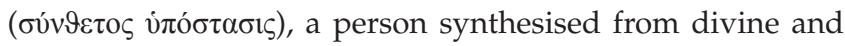
human nature.

It was within this framework, that the soteriological meaning of Christ was expressed. Christ saves, because he shares our human nature with us and ties that nature to the divine. Thus, salvation becomes an event of ontological significance and an objective, even cosmic, transition. We cannot elaborate on the different and intricate versions of how different dogmatic traditions fleshed out the union of both natures. In the context of our inquiry we are mainly interested in the fact that incarnation and salvation through Christ were understood as the divinisation of human nature by getting assumed through the divine logos. And the defect that was overcome by this process was not only sin, but included the deliverance from the weaknesses of human nature as a consequence of sin, that is human mortality, human perishability and human suffering. Especially death is at the centre of early Christology, since in the phenomenon of death everything is contained that characterises human natural existence corrupted by sin: disobedience, rebellion against God, the turn towards futility and evil, and final decay. Ontological salvation and restoration is necessary, because sin is not just correctable misbehaviour, but an ontologically destructive force affecting human nature as the essence and purpose of human existence. As Athanasius (298-373) wrote in his treatise on the incarnation:

Now, if there were merely a misdemeanour in question, and not a consequent corruption, repentance were well enough. But if, when transgression had once gained a start, men became involved in that corruption which was their nature, and were deprived of the grace which they had, being in the image of God, what further step was needed? (De inc. 7)

Repentance alone could not meet the case. It was human nature which had to be healed, and that was done by Christ who united mortal human nature with his immortal divine nature, who shared our fate of death, but because of his divine nature turned his death into a sacrifice and conquered death in his resurrection, by which he healed human nature from all corruption: 'And thus He, the incorruptible Son of God, being conjoined with all by a like nature [original: $\sigma \tilde{\omega} \mu \alpha$ ], naturally clothed all with incorruption, by the promise of the resurrection' (Athanasius, De inc. 9). Athanasius and many other contemporary theologians had an understanding of the death of Christ as a sacrifice and as paying the debt for human corruption, but the decisive process of redemption was the restoration of human nature which endows it with immortality and offers eternal bliss. It is the power of the incarnate and risen Logos which performs this restoration: 'God the Word of the all-good Father [did] not neglect humankind [original: $\gamma \varepsilon \dot{v} v \varsigma$ ], [which was] His work, going to corruption; ... restoring all that belonged to human beings by His own power' (Athanasius, De inc. 10). Or, as Gregory of Nazianzus (329-390) later put it: 'For that which He has not assumed He has not healed; but that which is united to His Godhead is also saved'. ${ }^{7}$

\section{Christian ontology: Between mythos and logos}

However, a strong ontological reading of traditional Christology is not without alternatives. Charles Lindbeck, for example, has pointed to the fact that even Athanasius as one of the fathers in the early church who was most responsible for the predominance of Nicaean Christology thought of the notion of consubstantiality 'not as a first-order proposition with ontological reference, but as a second-order rule of speech' (Lindbeck 1984:94), when he interpreted it as the principle that whatever is said about the Father is to be said about the Son as well, except that the Son is not the Father. But one could also refer to one of the earliest testimonies of the intentions of traditional Christology, the so-called Second Epistle of Clement, a transcript of a homily or sermon by an anonymous author, written around the middle of the second century. Right at the beginning the author addresses his audience by inculcating:

Brethren, we ought to think of our Lord Jesus Christ as of God, as of the judge of the living and the dead, and we ought not to think meanly concerning our salvation. (2 Clem 1:1)

Here, as well, a certain way of thinking rather than a distinctive object of thought is promoted as the aim of Christology.

This is also illustrated by the debates at the end of the 4th

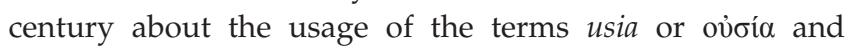

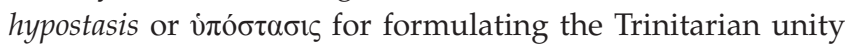
in diversity. Such a debate between different groups is documented in a letter that Athanasius sent home to Antioch after the official ending of the synod of Alexandria in 362. In this Tomus ad Antiochenos ${ }^{8}$ Athanasius reports that, after most of the participants had returned to their respective dioceses, some of the participants still present in Alexandria decided to explain to each other the different usage of the Christological and Trinitarian terms in question. What follows ${ }^{9}$ reads like an illustration of Wittgenstein's thesis that

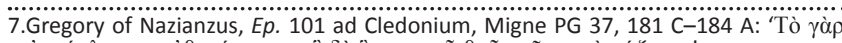

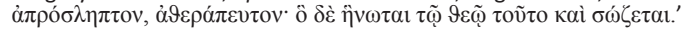

8.For the Greek text see http://www.athanasius.theologie.uni-erlangen.de/tom.html; for an English translation cf. https://en.wikisource.org/wiki/Nicene and PostNicene_Fathers:_Series_II/Volume_IV/Synodal_Letter_to_the_People_of_ Antioch/Tomus_ad_Antiochenos.

9.Athanasius, Tom. V 3-VI 3. 
linguistic meaning is use. Those who speak of three different hypostaseis are not asked for a definition of the terms, but for an explanation of their use: 'How then do you articulate this or why do you use such expressions at all?'10 After having accepted the hermeneutical explanation and defence of those expressions, it is the turn of those who speak of one single hypostasis. They also do not define the terms, but explain: 'we use the word hypostasis thinking it the same thing to say hypostasis or essence (usia or ovjoía); but we hold that there is one [usia], because the Son is of the essence of the Father, and because of the identity of nature' ${ }^{11}$ In the end, at least in this irenic report of Athanasius, 'after these explanations [hermeneias or $\dot{\varepsilon} \mu \eta \eta \varepsilon i ́ a \varsigma$ ]' all agree upon using the same words in the future in order to confess their faith.

As George Lindbeck (1984), Ingolf Dalferth (2015) and others have frequently argued, Christological categories and doctrinal decisions of the early church are indeed shaped by Hellenistic ontological thinking and formulated accordingly, but they transcended these notions by understanding the consensus of the church to provide first and foremost rules of speech to express the dynamics of the Christ event. They provide a grammar of faith referring to a dynamic and never fully explicable mystery rather than a static frame of reference to super-natural, objective matters of fact. Therefore, they can regain plausibility against their modern critics when theology avoids the mistake of an ontological reification of theological forms of thought.

Hence, Ingolf Dalferth claims that early Christian theology tried to develop a 'third' way of thinking contrasted with both, the mythos (narratives of Gods) and the logos traditions of antiquity. When referring to Jesus Christ, Christian theology neither offered a mythological narrative nor an a-temporal rationalist account of metaphysics (Dalferth 2015:xii). ${ }^{12}$ It is in Christology, where we find the fundamental and specific theological form of thought, which signifies Christian faith and characterises Christian theological thinking. It aims at expressing that God as Godself was present and acted in, with and under the actions of a historical human being. This specific human being was God's representative not because he was God in disguise, but because he was in his full humanity with all his existence referring to God as creator, as redeemer and as the future of creation and at the same time always applying this reference to different situations in which human beings find themselves.

\section{From ontology to juridical categories: A shift in medieval Christology}

As Albrecht Ritschl has pointed out in his voluminous work on The Christian doctrine of justification and reconciliation

10.Athanasius, Tom. V 4 , my emphasis.

11.Athanasius, Tom. V 6.

12.'Christian theology is neither a case of mythos or logos nor a combination of both, but something unique and sui generis' (Dalferth 2015:xvii).
(1882:31-47), in medieval times juridical thinking began to prevail over and against ontological thinking. This was partly due to shifts in the societal structure. In medieval Europe, Christianity melted with and deeply influenced European culture. Pre-Christian pagan traditions began to vanish, and with new forms of spirituality diffusing from the flourishing monasteries into broader strands of society and being communicated by preachers speaking in the vernacular of ordinary people, new modes of individual piety emerged (Taylor 2007:63-89). Lay people began to lead lives controlled and measured by biblical narratives and the role models of saints. An individual control of the conduct of life developed as well as individual forms of inward selfreflection. And it is no accident that in medieval times crucifixes, depictions of the dying or dead crucified Christ, became more and more important. In this context Anselm of Canterbury (1033-1109) moved the focus of Christology from ontological transformation to the juridical reconciliation of God and humankind. Atonement for humanity was necessary, because otherwise humankind would have been eternally lost and the goal of God's creation would have been missed. Jesus Christ through his death pays the debt of human sin and thus reconciles God with humankind. The immediate effect of Jesus' vicarious death is with God, not with human nature. It may have contributed to that shift from death and mortality to debt and satisfaction that medieval philosophical thinking had begun to take the immortality of the human rational soul for granted. Not death and mortality, not nature and cosmic ontology were the challenge, but obligation, guilt and responsibility. However, salvation still was mainly an objective process, which concerned human beings not ontologically, but juridically. And it was still a cosmic process, since salvation as achieved by the voluntary death of the divine-human person of Christ restored cosmic order and justice.

\section{Inherent limits of traditional ontological frameworks}

It has often been pointed out that all forms of metaphysical Christology as developed from a third-person perspective come under pressure in modernity. However, it is worth noting that in Christian theology right from the beginning there was a sometimes more, sometimes less developed awareness of the limits of the very ontological concepts which theology used. This awareness, however, did not lead to a search for alternative concepts and ways of expression, but is mainly reflected in the widespread caveat of negative theology, which in a way bracketed the whole body of theology as a human endeavour to understand that which is beyond understanding. This might explain the peculiar ambivalence of early Christian theology oscillating between strong ontological claims and humble, awestruck silence in its mystical traditions.

One issue that reveals the inherently aporetic design of the whole outset was the never-ending debate about the nature of individuality. In the case of God it was obvious for 
monotheistic thinking that God is not one of a kind. God or the divine is no class or nature which contingently happens to be instantiated only as one individual. God is God per se, and that is the point of monotheism. God is God's own being, and not one of a kind so that God 'has no nature', because his essence and existence coincide. Thus, to speak of the nature or essence of God which somehow is also exemplified in the human being Jesus of Nazareth is in itself problematic.

But ontological thinking in terms of natures, kinds, species and individuals ends up in aporetic puzzles for human beings as well. Individual human persons cannot be reduced to a contingent case of a universal human nature. The logical and ontological notion of an individual person follows very different semantic rules compared with general terms. This can already be studied in classic Greek philosophy. Plato and Platonism, with their turn towards the ontological prerogative of ideas, conceptualise the individual with categories such as participation $(\mu \varepsilon \dot{\varepsilon} \varepsilon \xi \xi \varsigma)$ in the idea, and the distinction between

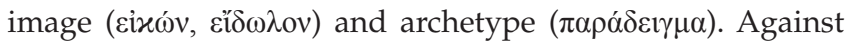
non-philosophical opinions, which hold that empirical individual objects are the only things real, Platonism defends an essentialist view.

Aristotle and Aristotelianism reverse the priority. Individuals

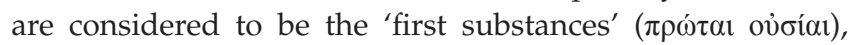
which are neither part of a subject nor predicable of a subject. ${ }^{13}$ An individual $(=\alpha \alpha \tau o \mu \rho \varsigma)$ cannot be divided without destroying what it is, and thus is numerically one ( $\tilde{\varepsilon} v \dot{\alpha} \rho \imath \mu \tilde{\omega}) .{ }^{14}$ Individuals have ontological priority over general terms, which he calls 'secondary substances' and which only reside in and are given with the individual. However, philosophical, scientific theory in an Aristotelian sense can only be developed with regard to species and genera, but not with regard to individuals. Even an individual geometric figure, like a concrete circle, cannot be defined, ${ }^{15}$ and Aristotelian thinking throughout medieval times has always kept the caveat that individuals do not fall into the scope of rational, scientific reasoning: 'individuals do not fall into the considerations of the arts' ${ }^{16}$ Later this principle was expressed with the famous phrase: 'the individual is ineffable' ${ }^{17}$

\section{Early modern philosophy}

While medieval Christology already supplemented transindividual categories like nature with collective juridical terms of satisfaction and vicarious representation, early modern philosophy developed new notions of personhood and individuality, which then became important for Christology as well. An early modern philosophy that tried

13.Cf. Aristotle, De cat. I 2 (10 7 ).

14.Cf. ibid., I 2 (1b 6); 15 (2a 11).

15.Aristotle, Met. VII 10 (1036a 5-6).

16.Thomas Aquinas, In libros meteorologicorum expositio I 1.1: 'individua enim non cadunt sub consideratione artis.' For the Latin/English version see http://dhspriory. org/thomas/Meteora.htm

17.This phrase is often referred to as a medieval principle. However, although it is fully in line with Aristotelian thinking, it cannot be verified in medieval literature, but in line with Aristotelian thinking, it cannot be verified in medieval literature, but
becomes popular in the 18th century when the individual in the modern, subjectivist sense gets into the focus of literature and philosophy. to combine Aristotelian and Platonist thought and was based on the notion of individuals as ontologically fundamental was the philosophy of Leibniz. According to Leibniz, only those entities can be regarded as ontologically fundamental that cannot be divided into parts. He, consequently, developed his notion of so called monads as 'the true atoms of nature' (Leibniz [1714] 1978:603). ${ }^{18}$ Ideas are abstractions on a higher level reflecting the order of reality consisting of infinitely many monads, and this order in the end refers to the universe of possible worlds which reside as nonextendable ideas in the mind of God and out of which God must have chosen the best of all possible worlds with all its monads to come into existence. Insofar as each monad represents the whole universe from its individual perspective, monads and worlds are mutually dependent notions. Thus Leibniz suspended an ontology of substances, natures and essences in favour of the fundamentality of distinctive individuals.

We cannot immerse further into the intricate and complex debates on the relationship between individuals and general or universal notions in modernity. We simply note that this relationship is precarious and demands explanation and differentiation, and traditional ontological and metaphysical thinking is not able to give a convincing account of this relation. Notions of 'natures' and 'essences' do not express what is 'essential' to individuals but rather help to describe and identify individuals, which can never be fully grasped and conceptualised. Individuals are beyond thought and language, so that there is no science of the individual. In a sense, individuals are transcendental.

In modernity science has further deconstructed the traditional ontological thinking of individuals as instantiating natures or essences. Living beings including humans are contingent results of an ongoing historical process (evolution). Concepts of what it means to be of a certain kind have fundamentally been historicised. Individuals are contingent formations of historical developments and settings.

All this is reflected in modern epistemology which points to the fact that all human understanding is not a representation of reality as such, but a construction relative to historically shaped notions and concepts. Today scientific perspectives refer to function rather than substance or essence. That does not mean that such a description is free of normative notions, especially when it comes to biological systems. Usually proper functions are distinguished from improper functions, genuine from secondary etcetera, and teleological categories seem inevitable. However, the modern scientific and much more formal approach renders concepts of 'sharing' a nature over times and classes of individuals meaningless.

This deeply shaped modern developments of moral philosophy with its stress on individual and nonsubstitutional notions of personality and responsibility. The 18.(\$3): 'Tes veritables Atomes de la Nature'. 
example of Kantian ethics may suffice to make that point. ${ }^{19}$ According to Kant guilt 'is not a transmissible liability which can be transferred to somebody else ... but the most personal of all liabilities' (Kant 1907:72). All notions of vicarious stepping-in have become mute. A personal individual is a unique and processual concurrence of natural, social and cultural traits. Human persons do not participate in a common nature, but realise non-substitutional ways of being human. Thus, the strong ontological link between the individual person Jesus Christ and the rest of humankind, which was decisive for traditional Christological thinking, is dissolved.

\section{Religion and Christology in an expressivist first-person perspective}

With modernity, classical Christology in an ontological, third-person perspective reading came under severe pressure and finally collapsed. In religious and theological terms, this was not only a destructive process, but in many respects also a liberating and constructive one. Early reformation theology already formulated fundamental reservations against a metaphysical framing of Christ's nature and focused on the soteriological meaning of Christ on an individual level. In his Loci Communes from 1521, Philip Melanchthon stated that to know Christ is not to contemplate his two natures and the modes of incarnation, but to know the beneficent meaning and action of Christ as a believer. Martin Luther, although in the end confirming his agreement with traditional doctrine, considered the doctrine of two natures secondary and instead wanted to enforce the importance of Christ's office and work:

For Christ is not called Christ for the reason that he has two natures. How does that concern me? Rather does he bear this glorious and comforting name from the office and work which he took on himself. (Luther [1525] 1899:217)

In Luther's view the constitutional character of Christ as one person in two natures is speculative knowledge and refers to Christ 'as such', but Christ's attention to the sinner and the love of God, which Jesus Christ incorporates, provide salvific, spiritual and transformative cognition which is relevant to us and thus a matter of ultimate concern. However, classical Lutheran and Reformed Christology developed new, even stricter ontological concepts of the personal, hypostatic union of the two natures in Christ. It was the liberal answer to the challenges of modernity that led to the abolishment of a high Christology of the incarnation of the divine Logos in a single human individual.

Consequently, not incarnation, but the human perfection of the religious figure of Christ became the centre of Christological reflection. Jesus Christ became the 'incarnation' of an exemplary religious human being, and the Reformers' quest for the office and use of the saviour became the central focus. This went along with a transformation of the understanding of religious language as 'experientialexpressive' (Lindbeck 1984:16) rather than designative or

19.One could point to Renaissance philosophy as well as to Socianism as early predecessors of this view. informative. Faith, belief and religious practice were seen as expressions of human self-understanding operating with symbols which in non-informative and non-discursive ways express inner attitudes, feelings and fundamental, prerational beliefs. From an object in front of the believer Christ turned into a mode of self-understanding always in the back or rather in the inner depth of the religious person. Thus, Christology was reshaped according to the principles of subjectivity (Moltmann 1993b:55) and humanity. Historical research discovered the historical figure of Jesus the Jew behind the biblical texts, and Jesus Christ was understood not as a divine, but as a human being with a special relationship to God. 'The gospel, as Jesus proclaimed it, has to do with the Father only and not with the Son' (Harnack 1990:91), with Jesus being the personal embodiment of the Gospel, not of God.

Applied to Christology this results in Christological models that see Christ as a historical figure and that do not promote faith in Christ, but faith like Christ, a Christ-like consciousness. For Immanuel Kant, for example, Christ as the Logos represents the idea of 'humanity in its complete moral perfection' (Kant 1907:60), but it is the Christ within us which is the criterion for this claim. And the historical figure of Jesus Christ is envisioned as this inner idea realised in a concrete historic individual, ${ }^{20}$ that is, as the 'ideal of a humanity pleasing to God' (Kant 1907:61). Insofar this idea is not empirical and cannot become a subject matter of empirical investigation, it is a concept that human beings experience within themselves and which they develop by reflecting on their self-understanding. This way Christology is developed from within a first-person perspective: on the one hand inspired by the vivid image of Christ as presented in the gospels, on the other hand produced and confirmed by the inner experience of the believers.

Schleiermacher draws Christological consequences out of this anthropology and tries to reconsider traditional doctrinal concepts accordingly. With regard to the Nicaean and Chalcedonian formulae he distinguishes between the councils' intention and the execution of it within the ontological framework, and asserts the first, but sharply criticises the latter. ${ }^{21} \mathrm{He}$ postulates that Nicaea and Chalcedon actually intended to express the specific personality (Persönlichkeit) of the redeemer (Schleiermacher 2008:61). He identifies two main objectives of the doctrinal formulations: to describe Jesus Christ in such a way as to express the new, vivid community (Lebensgemeinschaft) between human beings and Jesus Christ as their redeemer, and to articulate the presence of God within Jesus Christ as clearly as possible. This is not seen as an ontological puzzle of how to bring together human and divine nature within one personal individual, but as an expressivist task: to explain the intimate communion between Jesus Christ and all believers, while

20.According to Kant ([1787] 1911:595) an ideal is an idea not only in concreto, but also in individuo.

21.One can argue that Schleiermacher neither simply moved away from classical Chalcedonian Christology nor was his Christology a non-substantial revision in terms of the creed, but he rather provided 'a new synthesis of the mutually corrective christological positions that Chalcedon brought together' (Pearson 2003:350). 
simultaneously holding on to a fundamental asymmetry between Christ, who is 'unconditionally' venerated (Schleiermacher 2008:61), and all believers. Schleiermacher agrees with this intention, but identifies fundamental flaws in the doctrinal formulations, so that:

there is almost nothing in the execution [of this intention] against which protest must not be raised, whether we regard the scientific character [wissenschaftliche Beschaffenheit] of the expression or its suitability for ecclesiastical use [kirchliche Brauchbarkeit]. (Schleiermacher 2008:61)

Schleiermacher objects to the notion of two natures in one person, because nature is a term inappropriate for the eternal divine, and a person constituted by two natures is nonsensical. And he can make no sense of the notion of incarnation of the Logos as the second person of the trinity in the person of the redeemer: Trinitarian language and the concept of incarnation are mutually inconsistent. In effect, the ecclesiastical use of these concepts appears to be artificial and by no means plausible or helpful for believers.

Schleiermacher's own formula, which wants to keep the original intention to express simultaneously our community with and our dependence on the redeemer, is found in the heading of $\S 94$ of his Glaubenslehre:

Thus the Redeemer is equal to all human beings with regard to the identity of human nature, but is distinguished from them all by the constant potency of his God-consciousness, which was a genuine existence of God in Him [ein eigentliches Sein Gottes in ihm]. (Schleiermacher 2008:52)

Here Schleiermacher's ontological convictions are brought to bear: finite temporal existence and the divine cannot come together other than in the inner, personal and subjective world of consciousness. The distinction between us and the redeemer, then, is not in nature, but in God-consciousness, which in the redeemer is unhindered and always powerful. That allows for the establishment of a fundamental asymmetry: Jesus Christ is the productive archetype ('Urbild') and his God-consciousness is active, powerful and selfimparting (sichmitteilend), so that our God-consciousness is recipient and self-developing at the same time.

Speculative thinking has made this the central notion of philosophy that mind or spirit is its own source and subject, as Hegel (1894) asserts:

Mind is this absolute species, whose process is only the continual return into itself; thus nothing is for it which it is not in itself. ... the process of learning is not that something foreign enters in, but that the mind's own essence becomes actualised, or it comes to the knowledge [Bewusstsein] of this last. (p. 33)

In these kind of first-person perspectives Christology becomes the realisation and self-clarification of what it means to be religious in a Christian sense. In different variants, some more Schleiermacherian, some more Hegelian, this was and still is an important, and today maybe the predominant approach to Christology in German Protestant theology (cf. Danz \& Murrmann-Kahl 2011). To quote one voice out of many:
Christology thus is neither a part of theological dogmatics nor does it describe a historical figure, but it is an expression of transparency of the self-relation of mind [Bewusstsein] for itself in its individual realisation'. ${ }^{22}$ (Danz 2013:222)

In such types of Christology, in which the focus is on the inner world of religious individuals, Jesus becomes the image though in many cases surely rather a projection screen - for what we consider to be true religiosity, true faith and authentic existence. In a sense, Jesus becomes what we should be, so that Moltmann speaks of a reversal of perspective from incarnation Christology to a Christology of self-transcendence (Moltmann 1993b:81). However - as can be studied in the criticism of religion from the 19th century to today - Jesus can also become the symbol of what in a repressive religious perspective human beings should be, but what autonomous and self-determined individuals do not want to be, a repressive ideal of heteronomy.

With regard to Christology these views answer the objections and reservations of early Enlightenment against classical, ontological Christology. It takes seriously and even radicalises the fundamental presupposition of Western modernity that everything we experience and understand, we experience and understand in our own ways. Our categories, our language, our personal existence as self-reflective beings - all these are constitutive for and not derivative of understanding. And it can give credit to historical investigation and the integration of Jesus and Christianity into the history of religion, while it also puts Christ's office and work at the centre. From its very start this type of Christology is nothing but the unfolding of the meaning of Christ for us, though not with reference to objective processes and matters of fact, but with reference to our God-consciousness, whose emergence links us to Jesus Christ.

\section{Inherent limits of first-person Christologies}

However, there are also significant losses and shortcomings linked to these modern, expressivist reformulations of Christology. First of all, these interpretations cannot do justice to the biblical textual account. The New Testament texts are not interested in Jesus' religious personality. ${ }^{23}$ Rather, they put Jesus' preaching, his passion, his death at the cross and his resurrection into the centre as something beneficial for human beings, even when the disciples missed the point. The texts do not mention Jesus' own, personal assessment of his fate, but always present it as a series of events that effectively communicate God's mercy to human beings. Interpretations that seek to identify the meaning of Jesus by reconstructing the powerful religious consciousness of the historical Jesus are often prone to

22.Christologie ist somit weder ein Teilgebiet der theologischen Dogmatik noch beschreibt sie eine historische Person, sondern sie ist Ausdruck der Durchsichtigkeit des Selbstverhältnisses des Bewusstseins für dieses selbst in seinem individuellen Vollzug' (Danz 2013:222).

23.It aggravates the problem that a category such as the early-modern notion of religion linked to a distinctively religious worldview is anachronistic with respect to antiquity. 
arbitrary and anachronistic projections on the historical figure.

Secondly, liberal accounts have difficulties to express the basic Christian belief that God is effectively present in, with and under the formations of creation, including objectified reality. By building Christology around an interpretative structure of the inner world of religious human beings, they usually fail to give enough credit to what the reformers called the dimension of 'extra nos' (from outside our self). It is only because God reaches out to human existence mediated by external relations that God's actual reality is understood as something that is independent of human beliefs, but at the same time constitutive for it. Or as Martin Luther repeatedly claimed: 'God does not give internally except through what is external'. Only because of this in a sense eccentric structure of faith and human existence is it possible that certitude of faith emerges, which does not rest on the strength of inner convictions, but refers to dynamic processes of being won for faith by God's active presence:

And this is the reason why our theology is certain: it pulls us away from ourselves and places us outside ourselves, so that we depend not on our own strength, conscience, mind, person, or works but on what is outside us, that is, on the promise and truth of God, which cannot deceive. ${ }^{24}$ (Luther [1531] 1911:589)

Of course, to believe that God's active presence is independent of our beliefs is itself a belief (Dalferth 2006:137). There is no way to escape this common argument for turning away from Christian realism to religious idealism. However, to phrase it in Wittgensteinian terms, this is not just one belief of the many, more or less plausible things a believer believes, but rather a belief that is 'regulating ... all his life' ${ }^{25}$ It is not a belief inferred from evidence or other beliefs, but an organising and orienting principle deeply conjoined with the individual's conduct of life. It is important to understand such a belief, or rather faith, neither as acquired nor as freely chosen, but as unconditional acceptance and indispensable calling from beyond the individual's range of selfdetermination. It is my conviction that it is exactly in this respect that Christology has to be reformulated for our times.

\section{Christology and faith as participation in God's communicative activity employing second-person approaches}

We have argued so far that Christology shifted from being conceptualised within an ontological framework of objective and descriptive metaphysical realism based on thirdperson perspectives to interpretative, subjectivist accounts of religious consciousness from within first-person perspectives.

24.'Atque haec est ratio, cur nostra Theologia certa sit: Quia rapit nos a nobis et ponit nos extra nos, ut non nitamur viribus, conscientia, sensu, persona, operibus nostris, sed eo nitamur, quod est extra nos, Hoc est, promissione et veritate Dei, quae sed eo nitamur, quod est extra nos, Hoc est,
fallere non potest' (Luther [1531] 1911:589).

25.'Aber er hat das, was man einen unerschütterlichen Glauben nennen könnte. Dieser zeigt sich nicht durch Vernunftschlüsse oder durch Anruf von gewöhnlichen Glaubensgründen, sondern vielmehr dadurch, $d a \beta$ er sein ganzes Leben regelt (Wittgenstein 2000:76).
It turned out that both perspectives fall short of fully grasping the dynamic movement of the realisation of God's presence within creation and for human beings. However, they both bring to bear decisive aspects of Christology. Traditional Christology points to the indispensable ontological founding of God's agency in, with and under the forms of space-time reality so that reality becomes capable of effectively transcending itself and communicating God's grace. Traditional Christology clearly marked that this must not be understood as a super-natural transformation of humanity into the divine, but as an intimate union by which God at a certain point in history executed and thus revealed his ongoing and finally successful effort to transform human beings and establish communion with them. In this sense, any Christology must give credit to certain forms of Christian realism.

Liberal Christologies from within a first-person perspective, on the other hand, reject all kinds of reifications of classical metaphysics and insist upon the inevitable hermeneutical and interpretative nature of theological reflection as well as upon the individual, personal and engaging character of responding to God's incarnation in Jesus Christ. While classical two-nature Christology stands against any reduction of Christology to human self-understanding, liberal Christology argues against attempts to reduce Christology to a description of super-natural facts, against an implausible ontology of natures and essences, and against the exclusion of the individual. Both perspectives are limited; both put each other into place. Thus they call for a supplement which bridges the gap between both perspectives and at the same time counters attempts to fall either into Christological objectivism or subjectivism. In this last section of the article I want to sketch a concept of Christology that undercuts the divide between objective matters of fact, which human beings can only register, and subjective interpretations, which turn mute when relating to empirical perspectives of reality, by bringing in what I call second-person relations.

The point of a good distinction is not merely to classify but to enhance understanding, to clarify the force of argumentation, and to avoid puzzles. The solution for which I want to argue by employing the distinction between Christologies from third- and first-person perspectives is this: like in contemporary philosophy, we might overcome dichotomies between objectivist and subjectivist perspectives, between theories of the material world and theories of meaninggenerating consciousness by employing bridging principles of second-person relations. The argument for this is complex and would include profound elaborations on the relationship between empirically controlled, descriptive approaches towards reality, expressivist concepts of volition, agency, and personal identity, as well as their relation to cultural, semantic and historical notions, potentials and constraints (cf. Evers 2014). The aim would be to construct a self-supporting, complex structure of the interaction between all three perspectives without reducing reality to either matters of fact, or ways of thinking, or cultural constructs. 
Communication and communion as second-person relations are notions that both transcend concepts of ontological 'participation' through sharing nature, essence or substance, and transcend subjective symbolic self-interpretation. As we stated in the beginning of this article, God is neither identical with creation nor 'outside' of creation, but present within the process of creation. God is neither reducible to objective facts nor to a meaningful idea of subjective self-reflection. God is communicating God's life, spirit and love by drawing human beings into new forms of committed living exemplifying trust, hope and love. Reality in a Christian sense and informed by Christology is understood as a gift, a task, a calling, as well as a realm of enjoyment and pain mediated through communion and communication, which in the end rests on God's creative, transforming and inclusive communication of life for God's creatures as realised in Jesus Christ.

Reality then has to be understood as the interplay between objective facts resisting wishful thinking, the inward realisation and formation of consciousness striving for fulfilment of life, and relations of mutual encounter, of speech, of cultural and social forms of mutual participation culminating in love as the fulfilment of existence. Again there are limits to second-person relations. They must not usurp the individual self so that it is reduced to its social role. They must respect the mystery of the person and the dignity of the individual (first-person perspectives) by fostering relative freedom and self-determination of every human being. This, it seems, is the fear, sometimes getting close to an obsession, shared by many in Western societies, while other societies value community and sociality to a much larger extent. $^{26}$

On the other hand, and this is often neglected, secondperson relations must also be balanced with reality in a third-person perspective. No culture without nature, no consciousness without body and biology, no language without context. We cannot and we do not have to invent ourselves. We are not only what we make us to be, but we always have to form and cultivate our ways of life by making us of objective reality and by struggling with it. In such a view reality is seen as interplay of continuity and intermittence, of reliability and challenge. That implies that the divine-human relationship as well is misunderstood if seen as a unilateral relation of absolute dependence. It must comprise notions of relative independence, reciprocity and hiddenness. God is not the 'big other' (deus ex machina) whom we need to explain gaps, origins and goals, and God is not just resident as spirit or inspiration in our private inwardness. We need nuanced and differentiated concepts of divine presence and agency.

Therefore, we will get Christology right only if we closely link it to a complex notion of God's concurrent relation to creation and do not regard it as an isolated piece of doctrine. God loves everything by bringing it into being (as Father, and particularly related to third-person perspectives), by 26.One could think of the concept of 'ubuntu' in African cultures. inspiring it to explore more and more possibilities and opportunities through individualisation and socialisation (as Spirit, and particularly related to first-person perspectives), and by sharing and transforming its fate (as Son, and particularly transforming second-person relations).

With respect to Christology this is reflected in the fact that the name 'Jesus Christ' as God incarnate refers to a concrete story by means of which we learn about God's ever-present and liberating grace, and about our situation of hate and violence in the presence of God. We know about Jesus Christ only in the form of stories together forming a story of the birth, the death on the cross and the resurrection of the Son of God, a human being fully living in the presence of God and restoring and communicating this presence by being in full communion with God. The story of Jesus Christ is the story of God being in communion with human beings in human history. It testifies to the divine accommodation to our ways of living and God's passionate participation in the fate of God's creatures. And the story of Jesus reveals human wickedness without moralistic accusations. It discloses sin as a power-structure, which is unmasked during Jesus' passion and death as a mischievous interplay of individual failure, oppressive politics, degenerated justice, religious obsession and self-justifying public morality (Welker 2014).

The first Christians understood Christ as the Word of God. They communicated stories and held communion among each other by celebrating the recapitulation of Jesus' last supper, thus becoming part of the story of Jesus themselves. They began to understand themselves as the body of Christ through which the story of God in communion with human beings as proclaimed and mediated by Christ is continued. And they understood their participation in the story of God as a calling to show solidarity with their neighbours, to spread the story not just by repeating it, but by interpreting and applying it to ever new contexts and challenges. Revelatory communication (Christ as the Word) and reconciling communion (the body of Christ) were inseparable right from the beginning.

However, what Christianity partly learned in the last centuries and what it is still in the process of learning, is that God has used God's union with the story of a particular human being not to elect a chosen few, but to make God's ongoing loving and communicating presence unambiguously known. In the story of Jesus Christ God's eternal and omnipresent love has publically interpreted and effectively communicated itself. This implies that, when Christianity spreads globally, it does not bring God to other parts of the world, but it is part of God's long persevering mission of establishing effective communion between God and human beings. It meets God's love in other cultures, other religions and other stories, it identifies what Christ stands for in his ongoing mission and it is called to be part of God's communication and communion to draw human beings into loving God and loving their neighbours. Christian faith is not 
a preferment or a distinction, but a gift and a call to leading a life, which - in a particular place and time in history and in a particular way - participates in God's alliance with the fate of humanity as revealed and realised in Jesus Christ.

Understanding Christ as God's effective communicative act of love through the story of a concrete human individual also shows that God is not changing the world and human beings from the outside, neither by an authoritarian demonstration of power nor by changing the inner attitudes of people, but from within the context of human existence. Jesus Christ in his teaching does not define God, or provide extra information about God, but reveals God's contingent movement towards human beings while he also moves us to participate in God's movement.

Hence, Christology must be transformed from being an abstract theory or descriptive doctrine towards a specific form of doing theology. 'All the characteristic teachings of Christian theology are manifestations of thinking about God, human existence, and the world in Christological terms' (Dalferth 2015:xiv). Human beings can have faith in a person and events, but not in doctrines: we can believe in Jesus without believing in Christology. Doctrines try to develop something like a grammar of faith, but faith is not the acceptance of doctrines. Thus, Christology tries to unfold, explain and guide faith in Jesus Christ, but does not exhaust Christ's meaning nor adds anything to Christ. We need combinatory forms of Christology that link what we learn from the story of Jesus with the ways we lead our lives, we strive towards God and relate to our fellow beings. 'Completeness' in Christology is impossible and cannot be achieved by compiling a complete set of propositions about Jesus Christ. Christ is not adequately understood once we have the adequate theory about him, but if we make adequate use of him, because to believe in Christ means to accept him as God's gift of reconciliation and to participate in his office.

\section{Acknowledgements Competing interests}

The author declares that he has no financial or personal relationships which may have inappropriately influenced him in writing this article.

\section{References}

Athanasius of Alexandria, 1987, A select library of Nicene and Post-Nicene fathers of the Christian church, vol. IV, St. Athanasius: Select works and letters, P. Schaff \& H. Wace (eds.), T\&T Clark, Edinburgh.

Athanasius of Alexandria, 2006, Tomus ad Antiochenos, in H.C. Brennecke et al. (Hgs.), Athanasius Werke, vol. 2, Die Apologien 8, pp. 340-351, De Gruyter, Berlin.

Dalferth, I.U., 1991, Kombinatorische Theologie: Probleme theologischer Rationalität, Quaestiones disputatae 130, Herder, Freiburg im Breisgau.

Dalferth, I.U., 2006, Becoming present: An inquiry into the Christian sense of the presence of God, Studies in philosophical theology 20, Peeters, Leuven.

Dalferth, I.U., 2015, Crucified and resurrected: Restructuring the grammar of Christology, Baker Academic, Grand Rapids, MI.

Danz, C., 2013, Grundprobleme der Christologie, Mohr Siebeck, Tübingen.

Danz, C. \& Murrmann-Kahl, M. (eds.), 2011, Zwischen historischem Jesus und dogmatischem Christus, 2nd edn., Dogmatik in der Moderne 1, Mohr Siebeck, Tübingen.

Ebeling, G., 1989, Dogmatik des christlichen Glaubens, Bd. 2: Der Glaube an Gott, den Versöhner der Welt, 3rd edn., Mohr, Tübingen.

Evers, D., 2014, 'Wirklichkeit - "Was der Fall ist" oder "Wie es Euch gefällt"?', in B.A. Weinhardt \& J. Weinhardt (eds.), Naturwissenschaften und Theologie II, Kohlhammer, Stuttgart.

Harnack, A. v., 1900, Das Wesen des Christentums, 2nd edn., J.C. Hinrichs, Leipzig.

Hegel, G.W.F., 1894, Lectures on the history of philosophy, vol. 2, E.S. Haldane \& F.H. Simson (eds.), Kegan Paul, Trench, Trübner \& Co., London.

Hülsewiesche, R., 1984, 'Monotheismus II', in J. Ritter, K. Gründer \& G. Gabriel (eds.) Historisches Wörterbuch der Philosophie, vol. 6, pp. 142-146, Schwabe Verlag, Basel.

Kant, I., 1907, 'Die Religion innerhalb der Grenzen der bloßen Vernunft', in Gesammelte Schriften Abt. 1: Werke, Bd. 6, Reimer, Berlin.

Kant, I., [1787] 1911, 'Kritik der reinen Vernunft, 2. Aufl., 1787', in Gesammelte Schriften Abt. 1: Werke, Bd. 3, Reimer, Berlin.

Leibniz, G.W., 1978, 'Nouveau Essais sur l'entendement', in C.I. Gerhardt (ed.), Die philosophischen Schriften von Gottfried Wilhelm Leibniz, vol. V, Hildesheim, Olms.

Leibniz, G.W., [1714] 1978, 'La Monadologie (1714)', in C.I. Gerhardt (ed.), Die philosophischen Schriften von Gottfried Wilhelm Leibniz, vol. VI, Hildesheim, Olms.

Leibniz, G.W., 1987, Die philosophischen Schriften von Gottfried Wilhelm Leibniz, vol. II, C.I. Gerhardt (ed.), Hildesheim, Olms.

Lindbeck, G.A., 1984, The nature of doctrine: Religion and theology in a postliberal age, Westminster Press, Philadelphia, PA.

Luther, M., [1525] 1899, Reihenpredigten über 2. Mose 1524/27: 17 Dominica lubilate (1525)', Weimarer Ausgabe.

Luther, M., [1531] 1911, 'Galaterbriefvorlesung 1531', Weimarer Ausgabe.

Moltmann, J., 1993a, The Trinity and the Kingdom: The doctrine of God, Fortress Press, Minneapolis, MN.

Moltmann, J., 1993b, The way of Jesus Christ: Christology in messianic dimensions, Fortress Press, Minneapolis, MN.

Pearson, L., 2003, 'Schleiermacher and the Christologies behind Chalcedon', Harvard Theological Review 96(3), 349-367.

Peterson, P., 1994, 'Der Monotheismus als politisches Problem', in B. Nichtweiß (ed.), Theologische Traktate, Ausgewählte Schriften 1, Echter, Würzburg.

Rea, M.C., 1995, 'The problem of material constitution', The Philosophical Review 104(4), 525-552. http://dx.doi.org/10.2307/2185816

Ritschl, A., 1882, Die christliche Lehre von der Rechtfertigung und Versöhnung, Erster Band: Die Geschichte der Lehre, 2nd edn., Adolph Marcus, Bonn.

Schleiermacher, F.D.E., 2008, Der christliche Glaube: Nach den Grundsätzen der evangelischen Kirche im Zusammenhange dargestellt, Zweite Auflage (1830/31), Teilband 2, Rolf Schäfer (ed.), KGA I/13-2, De Gruyter, New York.

Taylor, C., 2007, A secular age, Harvard University Press, Cambridge, MA.

Wittgenstein, L., 2000, Vorlesungen und Gespräche über Ästhetik, Psychoanalyse und religiösen Glauben, C. Barrett (ed.), Fischer-Taschenbuch-Verlag, Frankfurt am Main. 